Климова Александра Сергеевна

студентка

Колузатов Владислав Юрьевич

студент

\title{
Рабунец Алексей Михайлович
}

студент

ФГОБУ ВО «Финансовый университет при Правительстве Российской Федерации»

г. Москва

DOI $10.21661 / r-462458$

\section{СТРАХОВАНИЕ ОТВЕТСТВЕННОСТИ ЗА КАЧЕСТВО ПРОДУКЦИИ В РОССИЙСКОЙ ФЕДЕРАЦИИ}

Аннотация: в представленной статье авторами рассказывается о том, что из себя представляет страхование ответственности за качество продукциии, уточняется также, кто и при каких условиях её использует.

Ключевые слова: страхование, ответственность, продукция, имущуественные интересы.

В настоящее время люди всё чаще и чаще обращаются за компенсацией убытков, полученных от использования некачественных товаров (услуг), и это имеет устойчивую растущую тенденцию, и время, когда российское покупатели и пользователи станут подавать иски в суды, пеняя на некачественно составленную инструкцию или дорогие часы, которые остановились после недели использования, уже не за горами. В сложившейся обстановке и производителям, и продавцам стоит подумать о страховании ответственности за качество продукции и услуг.

Сейчас во всём мире практикуют страхование ответственности за качество товаров. Более того, многие магазины просто-напросто не примут у вас продукцию, если вы не застраховали подобные риски. В странах, где компенсируется не только недоброкачественный товар, но и моральный ущерб, который может 
исчисляться сотнями тысяч долларов, страхование ответственности за качество продукции товара является актуальным и разумным способом защиты от возможных рисков и убытков. Покупатель, приобретая товар, заключает договор купли-продажи с продавцом, и, соответственно, получает право требовать с него возмещение убытков, если этот убыток произошёл из-за проданного продукта или услуги. В свою очередь, продавец, заключивший договор поставок с производителем, может потребовать компенсацию своих расходов на покрытие убытков покупателя. Следовательно, страховать ответственность за качество продукции товаров необходимо и полезно именно производителю. Таким образом, и продавец, и покупатель смогут быть уверены в том, что их расходы будут покрыты страховщиком.

При ненадлежащем качестве товара или услуги потребитель вправе потребовать от продавца (производителя) возмещение стоимости. В законе обозначено [1], что при наличии дефектов покупатель может требовать или устранение недостатков за счёт производителя, или, при отсутствии возможности устранения неисправности, обмен на новый аналогичный товар или услугу, или полное возмещение стоимости, включая стоимость экспертизы по выявлению недостатков (если потребуется). Помимо этого, если некачественным товаров были получены повреждения, компенсация покрывает и это.

Из вышесказанного следует, что договор страхования требуется для продавцов, производителей товаров и ответственных за исполнение работ или услуг перед потребителями за качество работ и продукции. А именно:

- предприятия общепита;

- обслуживающие предприятия (химчистки для одежды, мойки автомобилей, дома быта и т. д.);

- торговые компании (включая занимающиеся оптовой и розничной торговлей, супермаркеты, торговые центры т. д.);

- предприятия и организации, занимающиеся продажей товаров, а также оказанием услуг. 
При страховании ответственности за качество продукции объектом страхования являются имущественные интересы страхователя, которые связаны с обязанностью последнего, в соответствии с гражданским законодательством и Законом Российской Федерации «О защите прав потребителей» и иными законодательными актами Российской Федерации, регулирующими отношения в различных сферах деятельности, возместить вред жизни, здоровью или имущество третьих лиц, а также убытки, наступившие в связи страхового случая, предоставлением услуг с недостаткам ненадлежащего качества или недостатками оказываемых услуг, а также предоставлением страхователю утаенной или недостоверной информации о работе (услуге) в отраслях производства и оказания предоставляемых услуг.

В России ответственность продавца и производителя (товаров или услуг) регулируется Гражданским кодексом Российской Федерации, Законом Российской Федерации «О защите прав потребителей», а также нормативными актами в соответствии с иными федеральными законами и правовыми актами РФ.

Страхование ответственности за качество продукции осуществляется при определённых условиях:

- страхователь должен иметь разрешение на производство продукции, правильно оформленное в соответствии с законодательством;

- на товары выдан сертификат, в соответствии с законодательством обязательной сертификации;

- установлены чёткие и однозначные требования к показателям качества продукции, которые соответствуют требованиям закона РФ «О защите прав потребителей»;

- страхователь по требованию страховщика может предоставить документальное подтверждение о соответствия условий производства установленным требованиям к качеству продукции.

Страхование ответственности за качество продукции товаров является единственным финансовым инструментом, который выгоден, как и производи- 
телям, так и потребителям [2]. Это подтверждается опытом стран с развитой рыночной экономикой. Покупатели получают дополнительные гарантии оперативной и эффективной реализации их законных прав, вне зависимости от добросовестности продавца. А продавцы (изготовители), покупая страховой полис, освобождаются от вероятных убытков, вызванных причинением вреда вследствие выпуска и реализации недоброкачественной продукции.

\section{Список литературы}

1. ГК РФ Статья 503. Права покупателя в случае продажи ему товара ненадлежащего качества.

2. Цыганов А.А. Российские страховые компании: страхование ответственности за качество / А.А. Цыганов, Л.В. Бесфамильная // Финансы. - 2001. 